\title{
Appearance of lifereform elements between 1920 and 1930 in journal called "Magyar Lányok" (Hungarian Girls) ${ }^{*}$
}

\author{
Bé́tA BALOG \\ ELTE PPK Neveléstdományi Doktori Iskola
}

\begin{abstract}
In the research the author examined life-reform elements in the journal, Magyar Lányok, which was for the purpose of preparing young girls for life. Most of this reserch was carried out in the National Pedagogic Library and Museum in Budapest to analyzing the documents, the journal volumes. This magazine existed for young adolescent girls to preparing for life, and gave advices in direct and readable form to ladies who will get married, including the household, decency, heart issues, body care and fashion. The research focuses on the journal's life-reform elements content, what aspects it appears as dressing, personal care, food and home decor. Are there any foreign links in the journal? Who write most of time in it and in what topic?
\end{abstract}

Keywords: life-reform, youth magazine, adolescent girls, preparing for life, document analysis

\section{INTRODUCTION}

The press has been of great importance in our country for centuries used as a source of scientific work, mainly through its wealth of information. Journals written for women represent a special category, because since the Enlightenment in Europe girls' education become more pronounced, so each page editorial targeted the female gender as a separate readership. At the turn of the 18th and 19th century women's magazines began to transform in Europe, in the sense that starting to become more and more accessible for every social stratum, besides, from politics through fashion to gastronomy the palette of published themes

\footnotetext{
* A részkutatás az Eötvös Loránd Tudományegyetem Pedagógiai és Pszichológiai Karának Pedagógiatörténeti Kutatócsoportjában megvalósuló, Reformpedagógia és életreform - recepciós tendenciák, intézményesülési folyamatok címú OTKA-kutatáshoz tartozik. A kutatás legnagyobb része a budapesti Országos Pedagógiai Könyvtár és Múzeum (OPKM) épületében zajlott a vizsgált folyóirat-kötetek, dokumentumok tanulmányozásával, elemzésével.
} 
were really colorful. ${ }^{1}$ From the late 19 th century in our country the number of magazines for women grew, and now hundreds are available for young girls and for women.

The Hungarian women's magazines reflect a number of factors from the requirements set against Women by society (Kádár, 2002), and from characteristic features of the given era. With this in mind, I wish to examine within the framework of this study, that how appear the very determinative and highimpact movement, the so-called lifereform movement in a journal, Hungarian Girls, which existed for young girls who stand on the threshold of adult life. How appear the features of lifereform movements in the magazine like intends to return to nature, the emphasizing healthy lifestyles, the focusing on the individual, wanting to run away from mass standardization and mechanization in the difficult economic and social period fter the First World War. What does the newspaper highlight from the lifereform movement for the adolescent girls after the beginning of the movement.

András Németh's scientific evidence-based findings certify the relevance of my research questions and method choise: „The unfolding social reform movements'...big stream want to achieve essential changes in the individuum, in its mentality, at the cost of radical transformation of its world view, through reform of human life. In the narrower sense, lifereform related to this type of social movements. Their common characteristic is, that people wanted to realize the diserable existential changes which are important of the society. They wanted to achive this changes by ",back to the nature", "natural way of life", individual life, meal, residential environment and by reform of health preservation as well." Therefore, it is important, that this magazine can reflects the searching of new individual way, the specialities of lifereform movement and the reform thoughts of the young girls' teaching in the 1920s.

\section{About THE JOURNAL}

Hungarian Girls was a very popular journal which was published from 1894 to 1944 , in the begining twice in a month (at every month $1^{\text {st }}$ and $15^{\text {th }}$ ), than from 1922 three times in a month (at every month $1^{\text {st, }}, 10^{\text {th }}$ and $20^{\text {th }}$ ). We can say, that the magazine in its time was a niche in the sense that it was written specifically for young adolescent girls, which offered useful advices, practicals for eveyday life to girls in addition to entertaintmant and widening of general education, either in terms of their own career choices, whether in terms of appropriate preparation for the future care of their families. Around the turn of the century, there were other high standard pages for women, such as Nemzeti Nőnevelés (National Women Education) (1880-1919), but it equipped

\footnotetext{
${ }^{1}$ About the history of women's magazines, about international views see more: Kéri Katalin (1977): Női lapok a 18-19. század Európájában. Világtörténet. Ösz-tél. 74-78. o. http://kerikata. hu/publikaciok/text/noilap.htm letöltés: 2016-09-08 17:11
} 
women readers less for weekdays preparation techniques, rather it wanted to help in girl's, women's education with educational, scientific studies, topics. Several women's associations, women's organizations also issued regularly or intermittently newspapers nationally or regionally (for example Feminist Association Bulletin between 1906 and 1907), which aprroached largely in social and political aspects the instructions that appeared in the papers, less entertainment purposes. The journal called A Nő és a Társadalom (The Woman and Society) (1907-1913) worked with the similar porpuses like Hungarian Girls (for example preparation for motherhood, belles-lettres inquiry), but it was the official journal of the feminist women's movement, so it was not always present in the "quiet" communications, but the emancipation, women's suffrage and interpretation of women's roles in various fields were pronounced. ${ }^{2}$

The Hungarian Girls was a very long-lived magazine, which offered articles for fifty years to the readership. This magazine existed for the genteel middleclass young adolescent girls and gives advices in a direct, readable form for ladies who were before getting married. In what topcs? For example, householding, decency, love affairs, bodycare, issues of fashion and prepare for life. The editor of the journal in the era mentioned before was Anna Tutsek. She was writer and editor who had an independent career in the first half of $20^{\text {th }}$ century. In the first place she was popular in the circle of the conservative middle-class public.

The Hungarian Girls' permanent columns were Novels, short stories, dramas, sentimental novels told in sequels with moving, sometimes funny soulimproved stories; Poems; Educational publications, art, literature, history and housholding within practical advice for ladies who were before getting married, gardening, recipes and kitchen-advice, fashion and beautycare, ideas for needlework, light scientific educational publications, picture-puzzle, commercials, ads, post of editor and another permanent column was Pictures as notes of picture, source marking.

The number of the editoral messages among the columns of this magazine were especially high, in 1924 it was 60 percent of the writing (see: Pintér/Török, 2000. 2. táblázat). We can state that the young ladies kept in close touch with the editor who answered everyone in personal. The journal put values in the centre such as honesty, diligence, love of the country, nature and love of God. These were appeared and built-in in the stories, novels, tales, poems, educational publications as well.

\footnotetext{
${ }^{2}$ About The Women and Society in details, see: Kereszty Orsolya (2011): "A Nő és a Társadalom" a nők múvelődéséért (1907.1913). Magyar Tudományos Intézet, Budapest link: http://www . keresztyorsolya.com/sites/default/files/no_es_a_tars_keresztyorsolya.pdflast download: $2016-12-20 \quad 10: 49$
} 


\section{RESEARCH QUESTIONS, METHODOLOGY}

My research focuses that how practical advice, fashion and beautycare, light scientific educational publications reflect back the elements of lifereform, the effort to practical common sense in the column of Educational publications, art, literature, history and household of this magazine between 1920 and 1930. Are there any foreign references in the journal? All I implemented the method of document analysis in the Natonal Educational Library and Museum in Budapest, where many researchers had or has the opportunity to carry out scientific work on a variety of topics from its half million document files. ${ }^{3}$

The highlighted interval can be important, because the direct impact of postFirst World War welcome back to us through the pages of the journal. We can get to know, that within the relevant column, how it is reflected in the terrible events, besides, how appear the tensions easing, recovery from the war by "a new way" searching. In other words, we can learn, how the typical lifereform elements of the post-First World War appear in the newspaper, as it is important to consider the fact, that we can read in András Németh's study: "From the twenties onwards the social and human-forming fervor of the previous period were replaced by the synthesis, storage, the unchanging, absolute searching efforts. In parallel, it will also change the role of folk culture... The investigation is increasingly the subject of researching the national characteristics, the Hungarian spirituality." (Németh, 2013. p. 49.).

With document analysis we have the opportunity to collect data, quantitative and qualitative examine of explicit content and draw conclusions (Szabolcs, 2004). Taking into account respect Mária Nádasi's (2011) criteria for grouping documents, the examined journals can be classified as an official document, addressed to the "different general public." Within we can talk about an original and written document, because in that case research was conducted in concrete journal, which was both, the form and content of the original state it can be found and read.

Reading the test, there are eight major themes which I found important of research, focusing on researches questions which appeared in the magazine in the examined period:

1. Dining reform

2. Clothes to wear

3. Move

4. The culture of home

5. Gardening, plant growing

6. The community person

\footnotetext{
${ }^{3}$ About the National Educational Library and Museum's history see more: Droppánné Debreczeni Éva (2003): Az Országos Pedagógiai Könyvtár and Múzeum története 1. 1877-1933. OPKM, Budapest.; Droppánné Debreczeni Éva (2010): Az Országos Pedagógiai Könyvtár and Múzeum története 2. 19581990. OFI-OPKM, Budapest.
} 


\section{Society and family}

Reading about all of them, we may find that the effect of the First World War was quite perceptible even after the passing 5-10 years. In every case they emphasize the impoverishment, the need of the saving. I would like to specify the eight main themes I have highlighted this connection:

\section{TOPICS IN THE JOURNAL}

\section{Dining reform}

In all issues recipes were told in a part of the journal named Katóka a konyhában (Little Kate in the kitchen) by the editor, Anna Tutsek, for young readers through a story of a girl called little Kate who is taught the exploration and learning of culinary mysteries by her grandmother. This is a remarkably useful part of this column, becasue these many recipes are written by the editor for young girls in a simple, understandable way, what we can cook today as well. For example, in an issue plublished in 15. 01. 1920., little Kate lists various festive foods recipes (Christmas, New Year's Eve) for her friends (Tutsek, 1920. p. 22-23).

She emphasizes in many times that cooking the cheap dishes is the best under the circumstances. For example: "...In our days only the millionaires can cook manifold. For us, we have to be satisfied to eat only soup, boiled meat and pasta." (Tutsek, 1921. p. 357-358). That was why little Kate published such recipes which we can make in "better times" (steak with wine, steak loaded with carrot, light pasta chocholate). Inspired by this readership lived in hope of achieving a "better times" concerned.

In the early 20th century unfolding lifereform movement's base is everyday life more pleasant, healthy, naturally manifestation, which is an integral part of the vegetarian eating, organic farming and reform cuisine (Németh/Pirka, ed. 2013). The base of the reform cuisine is that we are to eat diversely, don't stay at only a few dishes, we should get to know more and more meal. The editor makes an effort to offer many cheap food to the reader as far as possible. On the other hand, the way of cooking and the ingredients marked the reform cuisine (for example preference of grains, vegetables, fruits, seeds, spices and herbs which are native to our climate - Szente-Kálmám, s. a.) don't appear in the recipes, but the tradional, regular procedures do in the gastronomy, such as using dairy products, which are not beneficial for the human body according to the reform cuisine because of the accumulation of toxins present in the large-scale livestock farming (Szente-Kálmán, s. a.).

\section{Clothes to wear}

According to lifereform, the best, the most naturally solution in the clothes to wear the natural clothes wearing, which does not restrict the movement, like 
waving, comfortable, sporty clothes and shoes. Preferring long skirt can include here, which ensures easy movement and also underlines the moral protection. In the analyzed period, the first half of the twentieth century, the long skirt was the distinguished mark of being big-girl. Around twelve the skirt started to grow, by eighteen it reached the ground, and with it there were different obligations and rights, for example welcome of admirers, going to theater at the evening, on Saturdays organization of dance-lessons instead of Sunday afternoons, dusting, mixing cake. "It was long time ago" - says Rózsi Benedek in 1926 - "but lately one can not state that who is little girl, who is big girl, because everbody wears short skirt and short hair, everybody wants to be young!" (Benedek, 1926. p. 426-427.). The reason is that the big girl needs to work a lot next to her mother, for her father misfortunes born of the war. During the First World War, a lot of women were forced to load the breadwinner role and provide heartland for the front-line-fighting men, for instance like semi-skilled worker, nurse, teacher, banker. Which in turn contributed to a slow transformation of a traditional, "be at home next to the stove and bringing up children" women's role. ${ }^{4}$ Ignore the corset is highlighted reform idea as restricting the freedom of movement. In addition, the fur to carry a critical judgment and in this context, emphasizing the importance of animal protection also appears in the journal (Sz. n. 1920, p. 10-11).

The topic of fashion also implies saving and living in grand style is condemned in an ironic way. "Each season had its clothes' budget even in modest families of the middle class, but there was changed this habit. Expenses paid to shoemakers, dressmakers, milliners, glove makers, did not follow fashion but the unavoidable needs, if it was possible at all... Men are not really crazy for fashion but for women causes pain this self-denial; they have to fight a battle with themselves." (Sz. n., 1920. p. 126-127). The journal condemns boasting, and draws attention to the fact, that saving money on fashion with every person, every family affected our country, not only a narrow social layer. This collective consciousness could help to get through the difficult period.

The topic of fashion covers other interesting themes in a historical context, for example about hairpiece or wig: during the reign of King Louis XIV. the so-called alonge wig become fashionable. The King hired 48 wigmakers who earned larger salaries than the officers of his court (Sz. n., 1920. p. 43-44). Perfumes: the article quotes the research of a French physician: those women who prefer strong scents (e.g. Patchoulli) are heartless and childish whereas those who prefer unobtrusive, fine scents (e.g. violet fragrance, cologne water) have many good qualities. The author state that based on a French medical research, which has studied the relationship between the female character and

\footnotetext{
${ }^{4}$ In the "First World War and women" theme see more: Higgonet, Margaret (1987): Behind the lines. Gender and the two world wars (Women's studies). Yale University Press.; Pukánszky Béla (2013): Bevezetés a nőnevelés történetébe. Mentor(h)áló 2.0 program. TÁMOP-4.1.2.B.2-13/1-2013-0008 projekt, Szeged.
} 
the perfume using. The preferred scents of some known historical persons are also mentioned: Nero liked rose, Louis XIV. preferred orange. Napoleon used a whole bottle of perfume every day according to the author (Sz. n., 1920. p. 60-61).

This theme reflects the simplicity, naturalness expectations, which fits on the one hand a small-middle class life, to follow fashion, and on the other hand interprets the phenomena within the framework of the reform efforts.

\section{Move}

The physical, mental and spiritual unity of existence, maintaining homeostasis is important in lifereforms, manifestationing in the body care, exercise, fascination for martial arts (Németh and Pirka, ed. 2013.). The column editor, Dr. Gabriella Kátai, answered the incoming letter in certain issues and published it with the following purposes: "Been disabled body can not live healthy mind, a lot of work is what life requires wants a healthy body. The Hungarian Girls would like to see that all the little Hungarian girl become strong, healthy and beautiful Hungarian woman. It will give you instructions as to how care the body, which is abode of the soul, which is God's most beautiful works and serious, busy human's working tool. The lazy man deserves to be nasty" (Kátai, 1926. p. 253-254). We can see, that in these words the harmony of body's and soul's culture appears, establishing a naturalistic, freikörperkultur reform movements ambitions, which "stressed the educational effects and beauty of natural move" (Németh, 2013. 27.), and which is closely in line with the reform efforts of natural clothing. This column stresses cosmetics, hair care with natural materials (soapy water, nut oil, lanolincream, rejection of hair dye), bath, preservation of the health of body (for example what to do against twisted spine) and the physical training. This reflects the extent of the lifereform movement, in terms of smoking and alcohol ignored abstinent lifestyle, natural body caring, which establishing a healthy lifestyle.

Although women's participation in the Olympics has been possible since 1900, around 1920 women's intensive sports was a big news and extravagance. In 1930s it is already natural and everbody keeps it necessary. But they emphasized that "with the taking down of the sports clothes the girl should be taking down the freedom with what she wants to emancipate with the man, and should be kind, gentle again, with good book and fancywork in her hands" (Sz. n ., 1930. p. 566). Equality, emancipation of women was therefore slow progress in different areas of life.

\section{The culture of home}

The interior design features regarding lifereform speciality on the basis of the read articles. Characteristics of lifereform movement are reflected in articles 
dealing with furniture by emphasizing good style, unaffectedness, moderation. One of the regular authoresses of the journal, Rózsi Benedek depicts a contemporary girl's room. She states that before the war furniture could be afforded but after the war even the simplest furniture became very expensive. But „need has taught us a lot of things and we are surprised to see how practical we are. What do we need and what can we prepare? - asks the authoress. A bookshelf, a desk for those who write a lot, a small table for those who do not, but can place a couple of flowerpots on it, some chairs, armchairs, some pictures on the wall and flowers everywhere in the flat." (Benedek, 1923. p. 151-152). We can say that this is good rhymes to Morris ${ }^{5}$ thoughts, who said that art should be equally beautiful and useful (Morris, recalls: Németh, 2013. p. 15).

Besides, the journal emphasizes the laying several times, which is simple, aesthetic and decorated with flowers from the nature, and it contributed to preparation for family life of middle-class girls. In 1926 came to light a presentation of the exhibition related to the National Association of Catholic Housewives which was about art of set table, for example an exhibition introducing related to laying in 1926. It appears five different kinds of dinner-service of ceremonies: wedding, 25th wedding anniversary (silver wedding), Santa Claus, young girl welcomes guests and Hungarian dinner. Even if this could not have been carried out in the same at home, with it they wanted to motivate the girls, that they have to make an effort to create the nicer, prettier home as far as possible. "From spring to late autumn forest and field give free the most varied, the most beautiful decorations of the table. We must try to fight our living standards fall of, because the point is not just what we eat but how." (Sz. n., 1923. p. 501-502). This description clearly reflects economic considerations.

\section{Gardening, plant growing}

This is also a preferred topic. It reflects the purpose of returning to nature, the advantages of country life. Articles give advice how to grow certain plants, flowers, indoor plants, fruit trees. An author remarks that few plants decorate the windows in Budapest although, there used to be more. The same author critisizes artifical flowers: "This awful thing became fashionable... (Számadó, 1921. p. 376-378). The reason for this is ponders: "Very few people trying to do the delight of growing flowers at home." (Számadó, 1921. p. 376-378). Ignoring the home decorating could be because of the grizzle caused by the war, because in the fighting of everyday living, immediately after the war, only a few people were able to reverse the problem of finding life's little pleasures.

Authors often draw parallels between grooving plants and upbringing, childcare. An anonymous author who writes about the care of houseplants formulates

\footnotetext{
${ }^{5}$ About the leader of the world-famous Arts and Crafts movement see more: Németh András and Pirka Veronika (2013, ed.): Az életreform and reformpedagógia - recepciós and intézményesülési folyamatok a 20. század elsö felében.Gondolat Kiadó, Budapest
} 
that "plants are like children. Each one beautiful, sweet, but resourceful is the one, who receive suitable mindful care, lovingly grow up, or to be tempered by the nature." (Kardos, 1921. p. 142-143). So, care, attention, affection ask for the plant as well. The artificial flowers criticizing János Számadó also provides that "Flowers are like children... Those who have a holistic view of children's lives and watch the development of children's fragile soul can love them with all their hearts." (Számadó, 1921. p. 376-378). In the case of "child-plant" metaphor the emphasis are on care and maintenance. The increase depends on the person who performs the care, and it is important that the conditions for growth are available. This can be an important reference, symbol for girls who read this magazine, on one hand regarding school education, on the other hand for the prospective mothers, who for through the treatment of plants show the defining essence of education as a guide. It seems to be the topic that gives evidence of lifereform attitudes in everyday life more than anything.

\section{The community person}

Natural behaviour is emphasized: „It is of no importance to know greetings, introducing each other and all the formal rules of social life, but natural behaviour, good impression, the adequate communication in each situation are important instead. One must be aware of the fact that even the nicest appearance cannot be make up for the inner values." (Benedek, 1922. 489-490.). It is not proper to be curious; curious people are inconsiderate and unreliable. „Curiosity can be converted into a thirst for knowledge. If somebody wants to know what his neighbours are talking about, it would be better to inquire about good recipes or how irregular French verbs can be most easily acquired (M., 1922. p. 78-79).

Behave properly is very important for a young girl: "I would like to resemble the young girl to the rose, which opens under the free sky of God wild and in its natural simplicity, or sparkles in well-kept gardens, parks. The park roses cultivate in art and culture. The right behaviour is worth more than the wealth... with which one can open doors and hearts easily" (Sz. Solymos, 1927. p. 78). From 1927 a column started called Right behaviour, in which they interpreted the right behaviour for girls in different places and occasions (at home, in tram, in theater, in company, etc.) because, as Sz. Solymos Bea also highlighted, the parental home and the school's shaping force are dominate in children's life, socialization.

We can see, that the teenage girls' proper behavior wishes to contemporary norms following, adapting to the expected values of the majority society, not accepted, criticizing the girls behaviors, which different from this rule system. This is more socialization and education issue and more refers to the social communication in this era, than refers to reform ideas of free and natural manifestations. 


\section{Society and family}

Because of the war, the deterioration of living standards, the impoverishment of the middle class occurred, with the result that the girls had to start work even after getting married. Many skilled workers, many educated women were seeking opportunities for earning bread. A new topic appears here: the educated woman. Besides domestic work intellectual activities are emphasized, and also the "Hungarian spirituality" exhortation: „Dear Hungarian girls, would-be mothers, please help build a happier country on the ruins of Hungary. Create in yourself the self- confident Hungarian girl!" (Papp, 1921. p. 245-246). Women who have hard circumstances to live need lots of virtues and logical thinking, as well. (Benedek, 1926, p. 373-374.). ${ }^{6}$

Articles on girls' vocational guidance are often published in the journal. In 1925 a new column was started titled "School life" referring to the progression of students and counselling girls to choose a profession. Articles refer to Germany where such activity is already in progress that lectures are held at schools to present certain professions and give personal advice as well. This methodology is also would like to achieved by the authors in Budapest, and there will be an example in a few years for that: From 1928 lecture series will start in relation to career choise and detailed description of the various useful professions by former schoolmates' alliance of Veres Pálné Grammar School for Girls. Also, they refer to the German sample, when they inspire the Hungarian girls for collective language-learning, with the so-colled Kränzchen girl-life institutions. Here, the same aged girls gather in every week and learn, play, read, do social work (for example they sew dresses for poor people), for this they collect money in such a way that everyone pays punishment when someone says only one word in her motherlanguage during foreign language learning.

The journal encourages the girls to the importance of education, to acquire adequate knowledge, the importance of reading as well: "Although the book is more expensive today, but it is still the cheapest entertainment and the only affordable gifts... the mind and body equally and without problems receive the necessary food." (Sz. n., 1923. p. 136-138).

Encourage them on the importance of education and training in the field of child-rearing as well. The 20th century was considered the century of the child's, in which the legislature, the technique, the art and science were serving to the developed new generation. But the war with undiminished ambition

\footnotetext{
${ }^{6}$ This reflects the finding that starting from the 1920s onwards a new approach appeared within lifereform movements, that "topics related to the lifereform of individual lifestyle went to the folksy rhetoric plane" (Németh and Pirka, ed., 2013) can be discovered. So the focusing on the national characteristics appears stronger in the movement's academic eloquence from this period, which backed by the Red Cross Youth's statement about -inter alia- "the fight against separating nations hate" through more issues, or the Theatre box, which appeared from 1921. XXVII. year 19.issue, and "improves and strengthens the Hungarian national sentiment" (Tutsek, 1921. 357-358.) by viewing the Hungarian actors performances in community.
} 
vetoed this: "The adults are not the only who feel every hard burden of the current heavy times,but also the children... So many years they lived in the sad atmosphere of constant fear for the father... The mother couldn't play happily with them, and they just see crying, fear around... The afflictions didn't even end by the end of the war. The Mother Fear hasn't been chased out from hearts." (Sz. n., 1926. p. 472-474).

Therefore, to mitigate this, they have been set up playgrounds by Red Cross leaders and supervisor "for playing Aunt" such as in Brussel, where professionals (teachers, social workers) organized game afternoons between 4 and $7 \mathrm{pm}$ a day, in 12 places in Budapest, for 4-15 years old children. The children play, get used to order and discipline. "The game afternoons are great witnesses to power of love and enthusiasm" (Sz. n., 1926. p. 472-474). The Red Cross has launched a course for the training of referees, where the enthusiastic participants can learn first aid, pedagogy, psychology, hygenics, children's songs, games among others, then, they closed at the end of the course with an exam.

The ambition of child's environment to fundamentally transform, a childcentered attitude and emphasizing of proper qualification of person, who deal with chldren are highlighted in this theme, as lifereform speciality. Besides that, the "rescue motif"7 also appears, sense that the children who grew up in broken families by the war also have enough time, place and possibility for free games, for practice different type of games, if their single mother has not enough time to play her children in addition to work. The trends of reformpedagogy, which bild on the child-centered school concept which is determinative today as well, came up with the lifereform movements (Németh and Pirka, ed., 2013).

\section{Summary}

In the lifereform movement which unfolding in the period between 1890 and 1914, people wanted to escape from crisis events which accompanying modernization, the industry, the rapid development of technology, the urbanization progress, and going from the negative effects to "individual is not focused", crowd phenomenas, attitudes. Escape to a lifeclosed nature, inwhich prevail the reform of individual life, healthy eating, the living environment and health preservation as well (Németh, 2011; Németh, Pukánszky és Pirka, szerk. 2014). It seems that the "back to nature" slogan of the lifereform movement is the consequence of the wounds of the war. As Ehrenhard Skiera stated: „People seek recovery to the wounds caused by civilization." (Skiera, idézi: Madarász, 2007). The effects of First World War can be detected both in the content and

\footnotetext{
${ }^{7}$ The rescue-motif of lifereform see more: Pirka Veronika (2013): Az életreform megmentésmotívuma, a korszak higiéniai diskurzusa és a gyermektanulmány összefüggései a 20. század eleji magyar pedagógiai sajtóban. In: Németh András és Pirka Veronika (2013, szerk.): Az életreform és reformpedagógia - recepciós és intézményesülési folyamatok a 20. század első felében. Gondolat Kiadó, Budapest. 97-116.
} 
style of the articles. In 1926 an author wrote: "During the last 11 years, the living standards of this whole fighting mankind, but mainly the defeated countries' citizens' became extremely decreased. The beginning of the war the biggest spares, the disclaiming of those things which were not necessary for living, became virtues. And then times passed away... Which was virute at beginning, now it is obligation; the watchword was: to spare. Everybody has to be satisfied with little, because the enemy's iron ring surround us" (Benedek, 1926, p. 21-23).

But the second half of the 20s some kind of optimism and fighting attitude slowly seems to be appeared for defeating of self-pity. "There can be no doubt that the saving pressure developed a big laziness and indifference in poeple. But one needs to have strong will, decision and desire for ordering life nicely. 'The way it was before, can be not', say with a bit resignation. . . in order to be a bit better it should not bother. However, it must be fight against the resignation with utmost vigor. However hard the life is, one has to try to balance with something, because the more one fights, works, the more one needs some beauty, rest and happiness. As soon as the economic climate improves slightly, it is important to girls' generation, who grew up during the war or misery in subsequent years, to want beauty and better, to desire the nicer home, creating a higher standard of living, not only the wanting of the new clothes, more shoes, nicer hats (Benedek, 1926. p. 21-23). The good soups, starter-foods and roasts appeared more and more in the recipes, mainly in the '29-30s and it refers to that they start to escape from the hardness of the war.

They emphasize that the only advantage of the war is that: "Year by year, more and more foreign people visit our country... Mainly from United States to Budapest because they are interested in our country where there are a lot of excellent musicians, great plays, nice pictures, interesting and colorful fancywork " (Benedek, 1928. p. 444-445). It may be added to the positive side also, that before the war women were "powerless puppets" but they became responsible, working citizens Kérczy, 2015). This process, however, took place as the consequence of the historical circumstances and was not a natural development.

An intention to "escape from urban areas and life" to natural way of life can be observed. Nevertheless, it does not mean the acceptance of a new way of thinking but it happens under the pressure of social-political life. The intent is perceptual, that 'escape from the town', from currents of city life fashion by natural ways of living. Changes of way of life such as dressing, girls'education, connection with nature reflect the effects of social-economic-political situation. The journal addresses middle-class girls, with slight references to lifereform movement.

We can say in summary, that the document analysis method provided the opportunity to analyse an exciting, original, contemporary journal, whichwith the reasearcher has opportunity to answer the research questions implying researcher sensitivity. As a continuation of the investigation, examination of the editorial content of messages can be exciting with contentanalysing in the 
Pedagógiatörténeti Szemle • 2. évf. 3-4. sz. 106-121. o. • 2016 DOI:10.22309/PTSZEMLE.2016.3.6

specific period of the journal, in terms of the appearance of lifereform elements.

\section{BIBLIOGRAPHY}

\section{Primary sources:}

Benedek Rózsi (1922): Pályaválasztás. Magyar Lányok, XXVIII. 16. sz. 254-255.

Benedek Rózsi (1922): Az illemről. Magyar Lányok, XXVIII. 31. sz. 489-490.

Benedek Rózsi (1923): Leányszoba. Magyar Lányok, XXIX. 10. sz. 151-152.

Benedek Rózsi (1926): Az otthon kultúrájáról. Magyar Lányok, XXXII. 2. sz. 21-23.

Benedek Rózsi (1926): Kenyérkereső munka és háztartás. Magyar Lányok, XXXII. 24. sz. 373-374.

Benedek Rózsi (1926): Kisleány-nagyleány. Magyar Lányok, XXXII. 27. sz. 426-427.

Benedek Rózsi (1926): Egyedül kell tanulni. Magyar Lányok, XXXII. 31. sz. 485-486.

Benedek Rózsi (1928): Amerikai lányokról. Magyar Lányok, XXXIV. 28. sz. 444-445.

Kardos Árpád (1921): A szobakertészet titkaiból. Magyar Lányok, XXVII. 9. sz. 142-143.

Kátai Gabriella (1926): Szépség és torna. Magyar Lányok, XXXII. 16. sz. 253-254.

M. (1922): Arról, ami nem illik. Magyar Lányok, XVIII. 5. sz. 78-79.

Papp Elemérné (1921): Az uj magyar lány. Magyar Lányok, XXVII. 16. sz. 245-246.

Számadó János (1921): Virágokról. Magyar Lányok, XXVII. 24. sz. 376-378.

Sz. n. (1920): A divat áldozatai. Magyar Lányok, XXVI. 1. sz. 10-11.

Sz. n. (1920): A vendéghajról. Magyar Lányok, XXVI. 3. sz. 43-44.

Sz. n. (1920): Illatok. Magyar Lányok, XXVI. 4. sz. 60-61.

Sz. n. (1920): Divat. Magyar Lányok. XXVI. 8. sz. 126-127.

Sz. n. (1923): Terítand. Magyar Lányok, XXIX. 32. sz. 501-502.

Sz. n. (1923): Olvasás fontossága. Magyar Lányok, XXIX. 9. sz. 136-138.

Sz. n. (1926): Játékdélutánok. Magyar Lányok, XXXII. 30. sz. 472-474.

Sz. n. (1930): Sport és lélek. Magyar Lányok, XXXVI. 36. sz. 566. 78.

Sz. Solymos Bea (1927): Helyes viselkedés I. Magyar Lányok, XXXIII. 5. sz.

Tutsek Anna (1920): Katóka a konyhában. Magyar Lányok, XXVI. 2. sz. 22-23.

Tutsek Anna (1921): Színház. Magyar Lányok, XXVII. 19. sz.

Tutsek Anna (1921): Katóka a konyhában. Magyar Lányok, XXVII. évf. 23. sz. 357-358. 


\section{Secondary sources:}

Kádár Judit (2002): “Otthonod az uradé". Három 20. századi magyar képes hetilap nőképe. Médiakutató. Tél. 78-94. Letöltés: http://www.mediakutato. hu/cikk/2002_04_tel/07_otthonod_az_urade 2016-09-08. 22:38

Kádár Judit (2013): Pályaeltérítés. Hogyan let Tutsek Annából lányregényíró? Kalligram Folyóirat, XXII. Január. Downland: http: //www.kalligram.eu/Kalligram/ Archivum/2013/XXII. -evf .-2013. -januar/Palyaelterites 2016-08-07 19:37

Kérczy Anna (2015): Hebrencs kisleányból kötelességtudó honleány. Médiakutató. XVI. 2. sz. 81-95. Downland: http://www.mediakutato.hu/cikk/ 2015_02_nyar/08_magyar_lanyok.pdf2016-08-07 23:02

Kéri Katalin (1997): Női lapok a 18-19. század Európájában. Világtörténet. Ösz-tél. 74-78. o. http://kerikata.hu/publikaciok/text/noilap.htm letöltés: 2016-09-08 17:11

Madarász Tibor (2007): Életreform and reformpedagógia - nemzetközi törekvések magyar pedagógiai recepciója. Recenzió. In: Új Pedagógiai Szemle. 57. évf. 9. sz. 188-190. Downland: http://epa.oszk.hu/00000/00035/00116/ 2016-08-07 22:56

Nádasi Mária (2011): Dokumentum- and tartalomelemzés. In: Falus Iván, Tóth Istvánné Környei Márta, Bábosik István, Réthy Endréné, Szabolcs Éva, Nahalka István, Csapó Benő and Mayer Miklósné Nádasi Mária (ed.): Bevezetés a pedagógiai kutatás módszereibe. Múszaki Könyvkiadó, Budapest, 263-273. Downland: file:///C:/Users/wd/Downloads/2011_0001_531_pedagogia\%20(2).pdf 2016-08-07 20:00

Németh András (2005): A századelő magyar életreform törekvései. Iskolakultúra. 2. 38-51. Letöltés: http://epa.oszk.hu/00000/00011/00090/pdf/ iskolakultura_EPA00011_2005_02_038-051.pdf 2016-09-08 22:31

Németh András (2011): A reformpeadgógia és az életreform mozgalmak kapcsolata. In: Fodor Antal et. al. (ed.): Perspektívák az új évezredben a táncmüvészetben, a táncpedagógiában and a tánckutatásban. Magyar Táncmúvészeti Főiskola, Budapest. 29-39. Downland: http://www . mtf . hu/download/1322218395. pdf 2016-08-07 22:48

Németh András (2013): Az életreform társadalmi gyökerei, irányzatai, kibontakozásának folyamatai. In: Németh András and Pirka Veronika (2013, ed.): Az életreform and reformpedagógia - recepciós and intézményesülési folyamatok a 20. század első felében. Gondolat Kiadó, Budapest. 11-54.

Németh András and Pirka Veronika (2013, ed.): Az életreform and reformpedagógia - recepciós and intézményesülési folyamatok a 20. század első felében. Gondolat Kiadó, Budapest

Németh András, Pukánszky Béla and Pirka Veronika (2014, ed.): Továbbélő utópiák - reformpedagógia és életreform a 20. század első felében. Gondolat Kiadó, Budapest

Pintér Szilvia and Török Andrea (2000): Az Én Újságom and a Magyar 
Pedagógiatörténeti Szemle • 2. évf. 3-4. sz. 106-121. o. • 2016 DOI:10.22309/PTSZEMLE.2016.3.6

Lányok címú gyermekfolyóiratok az 1910-es and az 1920-as években. Könyv and nevelés, 2. 4. sz Downland: http://olvasas.opkm.hu/index.php?menuId=125\& action=article\&id=184 2016-08-07 19:41

Szabolcs Éva (2004): Tartalomelemzés. In: Falus Iván (ed.): Bevezetés a pedagógiai kutatás módszereibe. Múszaki Könyvkiadó, Budapest. 330-341.

Szente-Kálmán Judit (s. a.): Mi az a reformkonyha? Downland: http: //erintesem.hu/mi-az-a-reformkonyha/ 2016-08-07 20:42

Vámos Ágnes (2001): A metafora felhasználása a pedagógiai fogalmak tartalmának vizsgálatában. Magyar Pedagógia. 101. 1. sz. 85-108. Downland: http://www.magyarpedagogia.hu/document/Vamos_MP1011.pdf Downland: 2016-08-08 11:51 